\title{
Designing WhatsApp Stickers With Madurese Cultural Identity as a Visual Communication Media to Raise Awareness of Coronavirus Disease (COVID-19)
}

\author{
Naufan Noordyanto ${ }^{1, *}$ Nugrahardi Ramadhani ${ }^{1}$ \\ ${ }^{1}$ Faculty of Creative Design and Digital Busines, Institut Teknologi Sepuluh Nopember, Surabaya, Indonesia \\ *Corresponding author. Email: naufan@its.ac.id
}

\begin{abstract}
The increasing number of Coronavirus Disease (COVID-19) cases in Island of Madura, Indonesia is not accompanied by people's behavior to contribute in preventing its spread, such as not implementing health protocols. Therefore, the public needs to be encouraged to increase awareness about it. The research explores on the method of applying the cultural identity of Madurese and COVID-19 message on designing stickers. For this purpose, we conducted observations and interviews Madurese people and stickers existing studies to understand design problem and literature studies to obtain sources of supporting theories. We used design methods by adapted and developed Brown's and Ambrose and Harris's design thinking method to create stickers. Finally, a set of sticker were created to be shared via WhatsApp and could potentially lead to participation and interaction with each other in the Madurese community to raise awareness about COVID-19.
\end{abstract}

Keywords: COVID-19, Coronavirus, Sticker, WhatsApp, Madura, Visual, Communication, Design

\section{INTRODUCTION}

The global spread of COVID-19 outbreak increases the number of deaths and the coverage of infected areas. The people are encouraged to protect themselves and others from the infection of COVID-19 by implementing health protocols suggested by World Health Organization (WHO) [1]. In fact, based on observations, especially on the island of Madura, where this research was conducted, some people still did not implement the health protocols. Some of those who do not have urgent business outside the home, actually still found hanging out, gathering, traveling, and so on. From the interview, the authors have examined the reasons why they go outside, such as: (1) they are bored if they continue to stay at home; (2) feel safe and not care about the outbreak, or (3) even some of them do not know about the COVID-19 health protocols. Besides, some of them are forced to do activities outside the home including working, shopping, etc. People were caught going in and out of high distribution of COVID-19 zone and did not wear mask, did not wash their hands, did not prepare hand sanitizers, cough without cover their mouths, and so on. Based on the author's findings, some of them argue that: (1) have difficulty breathing when wearing a mask; (2) feel uncomfortable to wear face mask and often wash their hands; (3) unwilling use/do it because they do not care about the outbreak as explained before; and (4) feel forced, some of them keep working to maintain their life although they feel unwell.

Based on the problems above, it can be understood that COVID-19 outbreak was not just a problem in the health sector, but also a cultural problem especially people's perceptions and behavior. If this cultural problem continues to be ignored, then it can already be imagined the number of COVID-19 cases will continue to rise. Therefore, the people need to be reminded and educated to be aware and sympathetic to reduce the spread of COVID-19 with the cultural approach.

So far, information about the health protocols have been widely socialized via the internet, mass media like $\mathrm{TV}$ or radio, print media, or outdoor advertisements, by governments and others. However, the socialization media have the nature of one-way communication, so that the audiences only become passive listeners/readers. The Madurese community, as the target audiences, is not possible to be directly involved interactively to participate in raising awareness about COVID-19. Besides, the scope of communication of the media mentioned above is wider, generally for national citizens, not specifically for Madurese whose cultural identity, including their language, are different. 
Therefore, a potential alternative visual communication media is needed to lead the participation and interaction of each other in Madurese community to raise awareness about COVID-19. One of the right media is WhatsApp stickers. Stickers offer a direct communication experience, interaction, presenting responses, not only makes the recipient just passively read. This is because stickers are used in chat and allow interaction. Even the stickers can be collected and continue to be shared by receivers to others. The use of stickers enables conversations that are entertaining, playful, and refine the message to be conveyed [2]. Stickers also become a medium for sharing thoughts and personal expressions without sending text typing. Therefore, the design and use of stickers is considered to be an appropriate, persuasive, and humanist cultural approach to raise awareness about COVID-19.

As a cultural approach, stickers have the strategic uses. The previous studies [3] found that the motivations of people to use stickers is also "self-representation -to express self as how one wishes to perceived by others-". The identity that is shown by someone and recognized by others can be accepted in group or community. In other words, self-representation can represent communal identity which refers to "cultural identity". The cultural identity is a characteristic shown by a person because that person is a member of a certain ethnic group [4]. It includes traditions, customs, language, religion, dress/appearance, and others [5]. Based on this concept, stickers that are presented with the Madurese cultural identity visualized on the stickers become a potential medium to reduce gaps and maintain social ties between individuals in community. That communication using local symbols (visual and verbal language) that are socially recognized in the community will be easily conveyed and accepted. This approach is potential to improve socio-emotionality among Madurese (as stickers users) and support the success of design objective.

We also consider the market opportunities and potential penetration of stickers and WhatsApp usage which tends to be high and become a trend. From 491 informants, 93.89\% informants of Madurese aged 17-40 years used WhatsApp and actively shared stickers. Only $6.11 \%$ informant not use sticker sharing for reasons: need more storage memory; not understand, intimate, and feel old to use stickers. Globally, the number of active users in April 2020, WhatsApp is the most popular instant messenger application with 2 billion users in more than 180 countries [6] [7]. Social media like WhatsApp had seen a $40 \%$ increase in usage due to outbreak [8]. Many people use social media to communicate during isolation or outside home.
There are a few numbers of existed stickers with the theme COVID-19 that had been distributed in Indonesia. On April 21, 2020, WhatsApp in collaboration with WHO released a set of stickers titled "Together at Home" in nine languages, including Indonesian [9]. In addition, there are also a COVID-19 theme sticker entitled "ITS COVID-19" with Javanese language in Surabaya dialect [10]; "Sunda Bodor ITS" with Sundanese [11]; and "Sticker edukasi COVID-19" visualizes a moslem lady figure who demonstrate prevention of COVID-19 in Indonesian language [12]. But the stickers are not specifically targeting Madura's audience. In addition, authors have not found the creative process and production stage of it which are recorded in the paper. Whereas previous studies on topics related to stickers are more likely to focus on general theories, such as discussing definitions, functions, uses, sticker circulation, etc. Thus, this paper focuses on (1) product contribution: designing WhatsApp stickers with Madurese cultural identity to raise awareness about COVID-19; and (2) developing an understanding, in the field of Visual Communication Design, especially the creative process and the production stage of it.

\subsection{Sticker on WhatsApp}

First, we need to discuss about emoticon and emoji, so that the sticker characteristics can be identified clearly. That terms, in the field of the computermediated communication (CMC), is known as "graphicon" [13].

Emoticon is symbol(s) that show the facial expression (mimic non-verbal cues) employed by typographic elements (letters and glyph) on text based instant messaging platforms [14]. While the term emoji have been adapted from the Japanese term "picture" $(e)$ and "character/letter" (moji) [15], mean two dimensional-pictorial [16] that are richer and more colorful than emoticon.

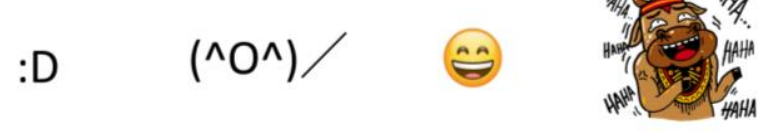

Figure 1 From left, examples of emoticon with horizontal style (left side) and vertikal style (right side) [17], emoji, and sticker on WhatsApp

The term "sticker" is used to describe the visual content, but on a larger scale, more complex and elaborate than emoji and emoticon, displaying more 
portraits of characters with body language and facial expressions that are more explicit than emoji -more demonstrative than symbolic- [2]. It mean that the message contained in the sticker is more presented with narrative demonstrations or illustration via visual or verbal language expression. Sticker can convey complex emotions/expressions rather than emojis. Based on the study of existing stickers, in one set of stickers, usually each sticker displays specific and different messages with different expressions. So, stickers can replace text messages because they play the role of visual communication media that speak descriptively through the visual language. The kind of this visual content are illustration/image only, tipography (short text), and sometimes both. The short text (verbal elements) is sometime embedded to support the explanation of the images.

According to interviews with users/informants, it is also known that the people uses stickers to: (1) emphasize messages; (2) clarify humor and make laugh; 3) make fun and exciting; (4) add cuteness; (5) playful; (6) opening and closing the conversation; (7) express user's personality; (8) fast and compact, because a sticker already speaks of a certain message than typing a text. Stickers receiver can be entertained, messages can be easily remembered, and make social relationships closer.

\subsection{Madurese cultural identity}

Madurese people live in the island of Madura, part of the East Java province, Indonesia. The geographical conditions of Madura, which are mostly limestone and dry areas, are thought to have contributed to shaping the character of Madurese society which is emphatic/strict and tough [18] [20] and tends to be expressive, emphatic, openness, and straightforward [19]. The community is known to have a strong spirit of brotherhood and solidarity as the basis for social relations so that the Madurese community networks in various places always exist. Based on observations, Madurese tend to interact closely with each other because they speak Madurese in everyday life. Like Javanese, the Madurese language also recognizes language levels: high level (known as èngghi-bhunten), mid level (èngghi-enten), and lowest level (enja'-iyyâ) [19].

The Madurese people is a community that is obedient in practicing Islamic system and making Islam a part of culture. [20]. Therefore they tend to obey the kiai, an traditional Islamic leaders as well as community leaders in social, cultural, and political matters.
The traditional clothes of the people of Madurese men are: oversized long-sleeved black shirt called pesa', red-white striped shirt, tall black cap called songko' or peci and headband called odheng. Madurese woman wears traditional cloths, such as kebaya, with contrasts color combination, with a hood or not, and a sarong, sampèr.

Some local tools such as sickles, hoes, and whips, they used while working. But Madurese will use different special sickles as a weapon when fighting (called carok) if they have social conflicts.

There are also a variety of well-known local herbal medicine (jamu), such as ramuan Madura to improve female health, and tongkat ajimat Madura, a kind of topical medication in the form of a stick to tighten female genitals.

The well-known Madurese tradition is raise cows for farming needs or trading, as well as specifically for involving in the tradition of karapan sapi or sapi sonok. Karapan sapi is a tradition that demonstrates the cows race competition. And sapi sono' is traditional female cows performance that walking like in a fashion show. These traditions symbolize prestige for the Madurese.

The Madura colors themed, based on our observations, tend to be primary, bright colors such as white, black, red, yellow, green, blue, and sometimes mix and match combination of contrast colors, as commonly used in traditional clothing, products carving, boat, and furniture, traditional boats and batik.

\section{METHODS}

The authors adapted and developed Brown's [21] and Ambrose and Harris's [22] design thinking method to create stickers, namely: (1) the stages of empathize (Brown's [21]) or research (Ambrose and Harris's [22]). (2) define; (3) ideate; (4) prototype; and (5) test (Brown's [21]) or implementation (Ambrose and Harris's [22]). Due the stickers are created and used to be shared, the final stage is the implementation and distribution stage.

(1) Empathize or research stage: authors conducted data collection, stickers existing studies, and literature studies to understand design problems. The result of this stage is described in the background and theoretical framework sections.

The author starts the empathize or research stage by collecting data. First, authors conducted field observations in Madura from March-June 2020, to find out community condition in dealing with outbreak. It should be noted that the first author is native Madurese 
and lived in Madura while making observations. Meanwhile, the second author lives in Surabaya and participated in observing the activities of the Madurese in Madura and Surabaya. Second, authors conducted first stage interview with 30 informants who were found still doing activities outside, what they were doing, reasons and objectives of their activities. During the outbreak, authors conducted online (second) interviews through WhatsApp in an unstructured manner with a number of questions prepared to investigate: did the people know and care about the danger of COVID-19 and how to prevent it? Why don't they implement the health protocols? how big WhatsApp users are and how old they are? and how much is the potential usage of stickers on WhatsApp? The number of informants in the all stages was 491 people. The authors also conducted last stage observation aims to collect data in the form of objects and others as part of the Madurese cultural identity, then visualized as stickers.

The other activities at the empathize stage are the authors studied the verbal and visual characters of WhatsApp stickers that have been existed and designed, specifically the stickers with the COVID-19 theme distributed in Indonesia. In addition, the authors also conducted literature studies to obtain sources of supporting theories about COVID-19, sticker, and Madurese cultural identity.

(2) Define stage: the authors formulated design problems and objectives, and determined target audiences based on the results of empathize stage.

(3) Ideate stage: the authors formulated design based on the design problems, objectives, and target audience. The author also conducted a study of user preferences by conducting interviews with several and random informants (on a small scale: 20 informants among all informants/491 people) via WhatsApp to validate visual or verbal preferences on stickers based on the results of the author's studies on existing stickers.

(4) Prototype stage: the authors visualize the design concept at the previous stage: (a) compose and classify messages (see Table 1); (b) create text in Madurese language; (c) Evaluate the texts for accuracy of words in the Madurese language. It was conducted by an informant, Tola'adi, a Madurese cultural activist from the well-known forum, "Pakem Maddhu Foundation" (focuses on the preservation and development of local language and literature in Madura, and the forum consists of writers, specialists, and Madurese linguists); (d) formulate ideas for visual content and illustration style, transform text to visuals (see 3.2.2); (e) sketch: illustrate characters of people or other relevant objects, facial expressions, gesture movements, and typography; (f) digitalization: inking, coloring on a square canvas 512 x 512 pixels, 72 dpi, and a transparent background; $(\mathrm{g})$ produce final design in PNG format (preview and finishing); and (h) transfer the final design (PNG) to the smartphone, then embedding through a third-party sticker maker apps, Sticker.ly, to produce a sticker package. In this process, the authors write the sticker title and the authors identity.

(5) Implementation and distribution stage: The sticker package was added to the WhatsApp application and tried to be used and shared. Stickers are distributed in two ways: (1) spread the link along with the screen capture preview of sticker pack uploaded on Sticker.ly, so users can first see the preview, and then go to the link and download it; or (2) share stickers one by one via WhatsApp when used in chat. We hope that these stickers will continue to circulate (shared) and be used more and more by the Madurese community.

\section{RESULTS AND DISCUSSION}

In this section, we discuss the define stage and the ideate stage. While the prototype stage and implementation and distribution stages are more technical steps and have been discussed in methods section.

\subsection{Define Stage}

\subsubsection{Design problem and objective}

The design problem is explore how to extract Madurese cultural identity and messages about COVID19 (Table 1) into WhatsApp stickers. These stickers will be able to be distributed to help people become more aware and sympathetic to the outbreak. The stickers are specially designed with verbal expression language and visual elements that represent Madurese cultural identities to demonstrate/deliver messages about COVID-19.

\subsubsection{Target audiences}

Target audience segmentations: (1) Demographics: based on research, the majority of WhatsApp users and those who are actively distributing stickers tend to be 17-35 years old; male and female; not limited to education and occupational levels; (2) Geographic: Island of Madura, and can be in other Madurese speakers territorries, both in Indonesia and abroad; (3) Psychographic: people who are interested in using social 
network media (WhatsApp) and sharing stickers; like the cartoons, high social care about the social health; and likes humor; (4) Behavioristic: people who are still active outside the home during outbreak; people who underestimate and ignore COVID-19; and people who care and are aware of COVID-19.

\subsection{Ideate Stage}

\subsubsection{Verbal expression language}

Based on the description in 1.2, we chose Madurese as the main language of stickers (Table 1). The Madurese language added to the stickers is the mix and match languages, both high level (known as èngghibhunten), mid-level (èngghi-enten), and lowest level (enja'-iyyâ) with the biggest portion. The speakers of lowest level are more common in Madurese community because this level is an everyday language and more familiar to the public. The Madurese language chosen is the Pamekasan dialect because it is relatively easy to understand widely. The choice of this language level and dialect is relevant, so stickers can be understood and accepted by the wider Madurese people. The writing of the words and its spelling in Madurese added on the sticker follows the General Guidelines of the Improved Madurese Spelling [23], both from the completeness of unique punctuation, such as vowels: " $\hat{a}$ " or " $a$ " and "è" or "e"; also consonants: "gh”, “dh”, “ny”, “jh”, and " $b h$ ". The speaking style and verbal expression designed on the stickers are adjusted to the personality and habits of the Madurese people to be expressive, emphatic, openness, and straightforward. The text are written in capital letters to express that personality metaphorically and emphasizing the message.

\subsubsection{Visual concept}

The sticker packages designed in this research are entitled "Madura Anti COVID-19 (part 1)" [24]. Authors designed 30 stickers based on Table 1, and it is possible to add more if needed even though this paper is finished. Based on the theories in 1.1., the visual contents of the stickers can be visualized from various objects, which are commonly familiar in Madurese community (Fig. 2).

Based on user preferences study, $84 \%$ of informants prefer stickers with an illustration rather than photos. Illustrations can freely express themes and concepts, and engage the imagination in fun even impossible ways rather than depicting something literally with photos. It created with digital painting techniques to demonstrate and express messages based on the verbal language we specified (see

Table $1)$. 
Table 1. Verbal expression language add to stickers

\begin{tabular}{|c|c|}
\hline Verbal (Madurese) & Description \\
\hline \multicolumn{2}{|c|}{ Advice regarding prevention of COVID-19 based on WHO's health protocols [1]: } \\
\hline $\begin{array}{l}\text { (1) Bâcco so sabun; (2) Jhâ' negghu' mowa mon tanang ghita' } \\
\text { èbacco }\end{array}$ & $\begin{array}{l}\text { Advice to keep hands clean and not touch face if } \\
\text { dirty }\end{array}$ \\
\hline $\begin{array}{l}\text { (1) Mon mangkat lako angghuy maskerra!; (2) Mon kalowar, } \\
\text { angghuy masker!; (3) Mon ablanjhâ, angghuy maskerra!;(4) Mon } \\
\text { aspèda'an, angghuy maskerra! }\end{array}$ & Advice for wearing a face mask \\
\hline Jhâ' pol-kompol! Agosip online bhâi! & $\begin{array}{l}\text { Advice to not gathering, but use online } \\
\text { communication }\end{array}$ \\
\hline Tahan kerrongnga, jha' toron ka Madhurâ ghâllu! & Advice to not going home from outside the city \\
\hline Sadhâjâ kodhu ikhtiar majhau dâri corona & Advice to encourage prevent COVID-19 together \\
\hline $\begin{array}{l}\text { (1) Mon ajjhiman, totop lèsanna!; (2) Jâgâ jara'en bi' oreng laèn } \\
\text { minimal } 1 \text { mètèr; (3) Ngèba handsanitizer mon ajhâlânan; (4) Jhâ' } \\
\text { salaman mon papasan }\end{array}$ & $\begin{array}{l}\text { Advice to comply with outdoor health protocols, } \\
\text { such as doing physical distancing, and closing } \\
\text { the mouth when sneezing }\end{array}$ \\
\hline $\begin{array}{l}\text { (1) Ė roma bhâi; Sholat è roma bhâi; (2) Ajhâr è roma bhâi; } \\
\text { (3) Kellonan è roma bhâi!; (4)Jhâ' kalowaran mon gherring; (5) Jhâ' } \\
\text { kalowaran mon tadâ' parlona; (6) Enom biddhangnga è roma bhâi }\end{array}$ & $\begin{array}{l}\text { Advice to stay at home or not leave the house if } \\
\text { you have not urgent }\end{array}$ \\
\hline Jhâ' tèdung mlolo! & Advice to stay productive, during outbreak \\
\hline \multicolumn{2}{|l|}{ Reminder and care: } \\
\hline $\begin{array}{l}\text { (1) Ngastètè!; (2) Sènga' Corona!; (3) Sènga' korban corona } \\
\text { bannyâ' la!; }\end{array}$ & $\begin{array}{l}\text { A reminder to be careful and aware to the } \\
\text { COVID-19 }\end{array}$ \\
\hline $\begin{array}{l}\text { Terros oladhi berita; (2) Jhâ' parcajâ kabhâr ta' bhendher bhâb } \\
\text { virus corona! }\end{array}$ & $\begin{array}{l}\text { Reminder to always update the news about } \\
\text { COVID-19 and be selective to avoid fake news }\end{array}$ \\
\hline Moghâ-moghâ corona èlang! Aamiin.. & A reminder to always pray for protection \\
\hline \multicolumn{2}{|l|}{ Additional phrases in chat: } \\
\hline (1) Sehat Ngghi?; (2) Maju a-video call-an!; (3) Saè! & $\begin{array}{l}\text { (1) How are you?; (2) Let us make video call!; (3) } \\
\text { OK! }\end{array}$ \\
\hline
\end{tabular}

Based on the description in 1.2, objects illustrated: (a) a Madurese boy and adult with a thick mustache wearing pesa', red-white striped shirt, songko' or peci, and odheng; (b) a young or old Madurese woman wears contrasts color combination cloths. The figures is illustrated by hold something, such as local equipments like a sickle, whip, or hoe. Another figure is illustrated: (a) represent kiai who is a role model for Madurese; (b) farmers; (c) health workers in hazmat suit hold the thermal gun; (d) a Madurese pet, cow figure called sapi sonok, with their unique decorative necklaces; (e) coronavirus character; (f) pocong ghost or shroud ghost character represents Indonesian ghost as a victim who died due to being infected with COVID-19; (g) other familiar objects in everyday life, such as, TV, smart phones, coffee cups and old teapots. As mention in 1.2., there is a cup of herbal medicine called ramuan Madura which is parodied to ask about audience health (Sehat Ngghi?) and Tongkat Ajimat Madura which is parodied to convey the message Kellonan è roma bhâi!; so that people stay at home by making love.

The stickers are illustrated with cartoon style, typically in a semi-realistic style. It intended to illustrate the characteristics of cuteness, funny/humor, and the impression of expressive stickers. The illustration of facial appearances, actions, gestures, supporting lines, and typography are made to support the convey of messages, especially based on the cultural identity of the Madurese people.

The stickers expression are designed with basic human expressions: anger, sadness, happiness, surprise, fear, and disgust [25].

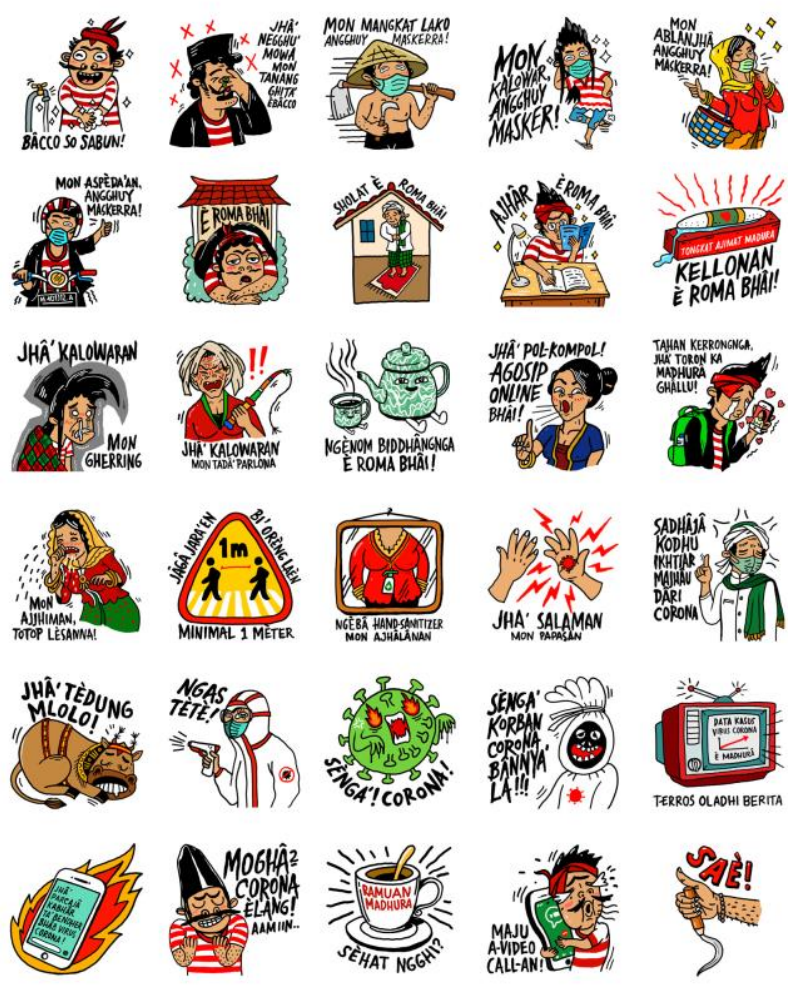


Figure 2 Stickers package "Madura Anti COVID-19"

The tone of the stickers are varied: parody and humor as the selling point of the sticker. This represents a humanist approach and subjective considerations. For example, in reminding others to be aware of COVID-19 which is a serious and frightening topic, we do not need to be strict and rigid. Instead we need to design and share stickers accompanied by humor and entertaining and full of intimacy, as the purpose of using the stickers as described in 1.1. The content of humor among Madurese is various, such as adult humor, funny words, etc.

Stickers are designed with simple illustrations and without more detail. Because the stickers tend to be relatively small in scale and cannot be enlarged to see the details. In addition, the simplicity of the stickers actually provides a focus on the message to be delivered.

Stickers are designed with a black outline to make it emphasizing the color and object of the stickers itself. The colors on the stickers are explored from the colors commonly used in Madura as mentioned in 1.2.

\section{CONCLUSION}

The research found that we need specific media and visual communication strategy with a cultural approach and the scope of local communication to raise awareness about COVID-19. The stickers with Madurese cultural identity can be used for this purpose. It can be shared via WhatsApp and potentially lead participation and interaction of each other in the Madurese community to raise awareness about COVID-19. This research does not focus on planning and implementing to distribute the stickers. Nor does it focus on post-creation studies, such as to examine community responses or how this sticker works among them. Both can be future research.

\section{REFERENCES}

[1] World Health Organization (WHO), "Coronavirus Disease (COVID-19) Advice for the Public,"
World Health Organization (WHO), 2020. [Online]. Available: https://www.who.int/

[2] A. Konrad, S. C. Herring, and D. Choi, "Sticker and Emoji Use in Facebook Messenger: Implications for Graphicon Change," Journal of Computer-Mediated Communication, vol. 25, pp. 217-235, 2020.

[3] J. Y. Lee, N. Hong, S. Kim, J. Oh, \& J. Lee, "Smiley Face: Why We Use Emoticon Stickers In Mobile Messaging," Proc. 18th International Conference on Human-Computer Interaction with Mobile Devices and Services Adjunct, pp. 760-766, 2016. Doi: 10.1145/2957265.2961858

[4] A. Liliweri, Dasar-dasar Komunikasi Antar Budaya. Yogyakarta: Pustaka Pelajar, 2004.

[5] N. Suryandari, "Identitas Kultural Masyarakat Madura: Tinjauan Komunikasi Antar Budaya," in Madura: Masyarakat, Budaya, Media, dan Politik, pp. 30-48. Bangkalan: Puskakom Publik and Penerbit Elmatera, 2015.

[6] WhatsApp Official, About WhatsApp, 2020. [Online] Available: https://www.whatsapp.com/about/

[7] J. Clement, Most popular global mobile messenger apps as of October 2019, based on number of monthly active users. Statista: Mobile Internet \& Apps, 2020. [Online]. Available: https://www.statista.com/statistics/258749/mostpopular-global-mobile-messenger-apps/

[8] S. Perez, Report: WhatsApp has seen a $40 \%$ increase in usage due to COVID-19 pandemic. TechCrunch, 2020. [Online]. Available: https://techcrunch.com/2020/03/26/reportwhatsapp-has-seen-a-40-increase-in-usage-due-tocovid-19-pandemic/

[9] WhatsApp Official, Introducing stickers. WhatsApp, 2020. [Online]. Available: https://blog.whatsapp.com/introducing-stickers

[10] ITS News, ITS Campaigns for Covid-19 Prevention Through Stickers. ITS News, 2020. Available:

https://www.its.ac.id/news/en/2020/06/09/itscampaigns-for-covid-19-prevention-through-itssticker-pack/

[11] D. Soenyoto, Sunda Bodor ITS, 2020. [Online]. Available: https://sticker.ly/s/FPZM6L 
[12] Bunda PAUD DKI Jakarta, Sticker Edukasi COVID-19, 2020. [Online]. Available: https://sticker.ly/s/QYFJQK

[13] S. C. Herring, \& A. Dainas, “"Nice picture comment!" Graphicons in Facebook comment threads," in Proceedings of then Fiftieth Hawai' $i$ International Conference on System Science, pp. 2185-2194, 2017.

[14] G. de Seta, "Biaoqing: The Circulation of Emoticons, Emoji, Stickers, and Chinese Digital Platform," in First Monday. vol. 23, no. 9. Chicago: University of Illinois, 2018. Doi: 10.5210/fm.v23i9.9391

[15] V. Evans, The Emoji Code: How Smiley faces, Love Heart and Thumbs Up are Changing the Way We Communicate. London: Michael O'Mara, 2017.

[16] R. Kelly, and L. Watts, "Characterising the Inventive Appropriation of Emoji as Relationship of Emoji as Relationally Meaningful in Mediated Close Personal Relationships," in Experiences ofTechnology Appropriation: Unanticipated Users, Usage, Circumstances, and Design, 2015.

[17] J. Park, V. Barash, C. Fink, \& M. Cha, "Emoticon Style: Interpreting Differences in Emoticons across Cultures," in Proceedings of the Seventh International Conference on Weblogs and Social Media, pp. 466-475, 2013.

[18] A. L. Wiyata, Mencari Madura. Jakarta: Bidik Phronesis Publishing, 2013.

[19] M. Syamsuddin, The History of Madura: Sejarah, Budaya, dan Ajaran Luhur Masyarakat Madura. Bantul: Arashka Publisher, 2019.

[20] Kuntowijoyo, Perubahan Sosial dalam Masyarakat Agraris: Madura 1850-1940. Yogyakarta: Mata Bangsa, 2002.

[21] T. Brown, Change by Design: How Design Thinking Transforms Organizations and Inspires Innovation. New York: Harper Collins, 2009.

[22] G. Ambrose and P. Harris, Basic Design 08: Design Thinking. Singapore: AVA Publishing, 2010.

[23] Balai Bahasa Surabaya, (2008). General Guidelines of the Improved Madurese Spelling (Pedoman Umum Ejaan Bahasa Madura yang
Disempurnakan). Surabaya. Balai Bahasa Surabaya, Departemen Pendidikan Nasional.

[24] N. Noordyanto, Madura Anti COVID-19 (part 1), 2020. [Online]. Available: http://sticker.ly/s/L582JZ

[25] H. N. N. Kumar, S. Jagadeesha, and A. K. Jain, "Human Facial Expression Recognition from Static Images Using Shape and Appearance Feature," In 2nd International Conference on Applied and Theoretical Computing and Communication Technology (iCATccT), pp. 598603, 2016. 